ORIGINAL ARTICLE

PRACA ORYGINALNA

\title{
THERAPEUTIC TACTICS IN THE DEEP FORMS OF RECTAL ABSCESSES COMPLICATED BY FOURNIE GANGRENE
}

DOI: 10.36740/WLek202002116

\author{
Oleh E. Kanikovskyi', Andrii V. Osadchyi', Sergey I. Androsov' ', Anatolii V. Tomashevsky', Oleh A. Yarmak', \\ Valentyn S. Bakhnivskyi2,3 \\ 'NATIONAL PIROGOV MEMORIAL MEDICAL UNIVERSITY, VINNYTSIA, UKRAINE \\ ${ }^{2}$ CRACOW UNIVERSITY OF ECONOMICS, CRACOW, POLAND \\ ${ }^{3}$ STEFAN ŻEROMSKI HOSPITAL IN CRACOW, POLAND
}

\begin{abstract}
The aim: To conduct an analysis of the complex treatment of severe forms of rectal abscesses complicated by NF.

Materials and methods: The results of treatment in 471 patients with deep forms of RA was performed. In 38(8\%) the spread of the process and rotten-necrotic affection of the perineal fascia. Patients were treated at the surgical clinic of the medical faculty №2, VNPMMU, and Vinnytsya Clinical Emergency Hospital in the period from $2010-2018$. Results: Total lethality $8(1,7 \%)$. Mortality in GF was $8(19,5 \%)$. It is worth noting the reduction of the treatment duration against the background of the modern technologies usage in the period from 2016 to 12 days in relation to the total figure of 15 days.

Conclusions: Early surgical treatment, adequate necrectomy, fasciotomy and antibacterial therapy stop the necrotic process. The active aspiration reduces the timing of wound cleansing and further ensures the accelerated implementation of reconstructive surgical interventions.
\end{abstract}

KEY WORDS: Rectal abscess, necrotic fasciitis, gangrene Fournier, sepsis

Wiad Lek. 2020;73(2):293-297

\section{INTRODUCTION}

Rectal abscess (RA) - a common disease that covers $1 \%$ of hospitalized patients in surgical hospitals, and reaches $5 \%$ among the diseases of the colon. [1] The incidence is, according to the Swedish cohort study, 16.1 per 100,000 population. [2] Approximately 70\% according to literature data are for male sex, due to anatomical features of the pelvic structure and sexual differences. [3] The main cause of the pararectal abscesses formation is the infection of anal glands in $90 \%$ of the cases. [4]

Necrotizing fasciitis (NF) of the perineum, spreading of suppurative necrotic process on the external genitalia and formation of Fournier gangrene (GF), development of sepsis - is one of the severe complications of pararectal abscesses. NF - severe clinical course of non-specific infection that is characterized by progressive necrosis of tissue, micronecrosis, high-grade intoxication and high mortality rate that reaches $76 \%$. [5.6]

Fighting with the progression of purulent-necrotic lesion in the cellular spaces of the pelvis affects both the outcome of treatment and the development of complications. [7] As the factors contributing to the development of necrotic fasciitis, the authors distinguish the following criteria: age older than fifty years, overweight, peripheral vascular impairment, immune deficiency, chronic alcoholism, diabetes mellitus, corticosteroid administration, drug injection and infectious complications in postoperative period [8]
Despite successes in the treatment of patients with acute paraproctitis and its complications, there remain a lot of questions regarding the choice of tactics, the management of this category of patients, which dictates the need for further research on the development of new highly effective and less traumatic methods of treatment of this pathology. [9]

\section{THE AIM}

To conduct an analysis of the complex treatment of severe forms of rectal abscesses complicated by necrotic fasciitis.

\section{MATERIALS AND METHODS}

The analysis of treatment results in 471 patients with deep forms of RA was performed. In 38 (8\%) the spread of the process and rotten-necrotic affection of the perineal fascia, thighs, anterior abdominal wall, urogenital area were revealed. Patients were treated at the surgical clinic of the medical faculty №2, VNPMMU, and Vinnytsya Clinical Emergency Hospital in the period from 2010 to 2018. Among them: men are 355 (75,3\%), women 116 (24.7\%). The age of the patients varied from 18 to 82 years (mean age 50 years). Patients with subcutaneous, submucosal and chronic paraproctitis were excluded from the study. 


\section{RESULTS}

All patients were hospitalized in an urgent manner with a clinical picture of purulent affection of anorectal and urogenital areas, signs of intoxication syndrome. The average duration of the disease was from 3 to 7 days. On inspection, local signs of purulent and purulent-necrotic affection were revealed: hyperemia, edema, local temperature increase, pain, skin necrosis, purulent discharge. Crepitation was found in $39(8.2 \%)$ patients, indicating anaerobic or association of aerobic-anaerobic flora. During hospitalization, general clinical and biochemical laboratory tests were performed, blood electrolytes and C-reactive protein were determined. All patients underwent ultrasonographic (CS) examination of the abdominal cavity organs, pelvic organs and soft tissues of perirectal and urogenital areas to detect purulent foci, and to determine the spread of the process. US was actively used CS intraoperatively, which allowed to achieve radicalism in the drainage of pelvic cavity. X-ray of the pelvis was performed in $27(5,7 \%)$, computer tomography in $14(2,9 \%)$ to determine the spread of the process and confirm the anaerobic lesion, which determined the air bundle of soft tissues. The defined localizations of the purulent process are presented:

Localization of RA: Ischiorectal 338 (71,7\%), retrorectal $57(12,1 \%)$, pelviourectal $35(7,4 \%)$, necrotic fasciitis of the perineum on the background of acute paraproctitis (Fournier phlegmon) 41 (8,7\%).

Short (up to 4 hours) and intensive preoperative preparation were carried out in the shortest possible time until the stabilization of homeostasis.

Operative interventions were performed under spinal $428(90,9 \%)$ or general $43(9,1 \%)$ anesthesia. For opening of purulent nidus, an arched incision was used in the projection of infiltration softening. Adequate necrectomy and revision of perirectal spaces were carried out. In the cases of purulent pouches, additional incisions were performed with aponeurosis and fascia opening for decompression and prophylaxis of the compartment syndrome.

During necrectomy tissue viability was determined on the basis of clinical signs: the presence of visible tissue destruction, change in their color, impregnation with pus, lack of shine during muscle contraction, degree of bleeding. The basis of adequate opening of abscess is visualization of the bottom of the wound, so the cuts should be sufficient for control. In order to improve the results of necrectomy use, "Sonoca400» ultrasound cavitation apparatus of the Soring company was used in $26(5,5 \%)$ cases. The cavities were cleaned in a retrospective analysis in $305(64,7 \%)$ with $\mathrm{H} 2 \mathrm{O} 2$ and decamethoxin, and in 166 (35,3\%) with PulsaVac system, a pulsating jet of ozonized solution with active aspiration. One of the stages of radical surgical treatment of acute paraproctitis is the excision of the internal opening in the crypt of the rectum, which was performed in $423(89,8 \%)$, and in $48(10,2 \%)$ due to the severity of the patient's condition, in cases of the advanced purulent-necrotizing processes excision was not performed. In ischiorectal, retroretal and extended purulent processes of the perineum cavities drainage with the usage of active aspiration systems was introduced. "ActiVac" device of the "KCI" company was used in $54(11,5 \%)$ patients. In pelviorectal paraproctitis and phlegmon of the pelvis, processes, spreading to the anterior abdominal wall, thighs, flow-washing US-guided system with antiseptics and active aspiration was mounted $11(2,3 \%)$. Operations was completed with drainage and plugging of the rectum with a rectal tube. Perineal wounds were not stitched.

Antibacterial therapy was performed taking into account the results of the bacteriological study and determination of antibiotic sensitivity and in accordance with the recommendations of the Sanford Guide. Adequate anesthesia was achieved by the administration of narcotic analgesics and combination of paracetamol infusion and intravenous administration of dexketoprofen.

Bandaging was made up to 6 times per day, after anesthetizing, with a careful wound revision and staged daily necrectomies till the pathology progression stopped. For extensive tissue defects vacuum wound therapy was used with subsequent autodermoplasty. Formation of pararectal fistulas was detected in remote results in 51 (10,8\%). Rectal sphincter insufficiency of I-II st. was determined in 27 (5,7\%), in 8 $(1,6 \%)$ of which surgical correction was performed - sphincteroplasty and narrowing of the anal canal in the cold period.

Total lethality $8(1,7 \%)$. Mortality in Fournier's gangrene was $8(19,5 \%)$. It is worth noting the reduction of the treatment duration against the background of the modern technologies usage in the period from 2016 to 12 days in relation to the total figure of 15 days.

\section{CLINICAL CASE}

Patient A., 60 years old was hospitalized in the surgical clinic of medical faculty №2 of VNPMMU on 10.12.2018. Major complaints were headache, dizziness, apparent general weakness, malaise, fever up to $39.5-40^{\circ} \mathrm{C}$, swelling in the anal and zone, scrotum, inguinal area, bursting pain in the infiltration zone, urinary retention, erythema of the external genitalia. It is known from the anamnesis that the patient was ill for 7 days when he noted moderate pain in the rectum. Gradually the swelling appeared and in the last 12 hours spread to the perineum and external genitalia. Increase in temperature to 38 was observed for 7 days. He was not treated at home, except taking antipyretic.

From life anamnesis: he is suffering from diabetes mellitus type II for 5 years, insulin-independent. Adjusts blood sugar with diet and siofor. Normosthenic type.

At the time of inspection: The patient's general condition is grave. BP-90/60 mmHg, Ps-110 per minute, RR-26 per minute, SPo2-97\%. The skin and visible mucosae are pale, dry. Tongue is covered with white fur. Vesicular respiration, tachypnea. Rhythmic heart sounds, tachycardia. On palpation abdomen is soft, painful in lower part, more on the right. Symptoms of peritoneal irritation are negative. On palpation - infiltrate over the pubis and in the right inguinal area. Delay of urination, urethral catheter is inserted.

Status localis: External genitalia are enlarged, scrotum, perineum, right perianal area are tight, with hyperemia. 
Table I. Multiple Organ Disfunction Sepsis Severity Evaluation System (SOFA) [Vincent J.L., Moreno R., the SOFA 1996]

\begin{tabular}{|c|c|c|c|c|c|}
\hline Points & 0 & 1 & 2 & 3 & 4 \\
\hline Respiration ( $\mathrm{PaO} 2$ / FiO2) & $\geq 400$ & $<400$ & $<300$ & \multicolumn{2}{|c|}{$<200<100$ with respiratory support } \\
\hline Coagulation (platelets x109/I) & $>150$ & $<150$ & $<100$ & $<50$ & $<20$ \\
\hline Liver (Bilirubin, mmol/l) & $<20$ & $20-32$ & 33-101 & $102-204$ & $>204$ \\
\hline Arterial hypotension & No & $\begin{array}{l}\text { AT }<70 \\
\mathrm{~mm} \mathrm{Hg}\end{array}$ & $\begin{array}{l}\text { Dopamine } \\
<5 \text { або } \\
\text { dobutamin } \\
\text { будь дози }\end{array}$ & $\begin{array}{c}\text { dopamine } 5-15 \\
\text { or adrenaline } \leq 0,1 \\
\text { or noradrenaline } \\
\leq 0,1\end{array}$ & $\begin{array}{c}\text { dopamine }>15 \\
\text { or adrenaline }>0,1 \\
\text { or noradrenaline } \\
>0.1\end{array}$ \\
\hline CNS, Glasgow Coma Scale & 15 & $13-14$ & $10-12$ & $6-9$ & $<6$ \\
\hline $\begin{array}{l}\text { Kidneys (creatinine, } \mathrm{mmol} / \mathrm{l} \text { ) or } \\
\text { diuresis }\end{array}$ & $<110$ & $110-170$ & $171-299$ & $\begin{array}{c}300-440<500 \text { мл } \\
/ \text { day }\end{array}$ & $>440<200$ мл / day \\
\hline
\end{tabular}

Table II. Fournier's Gangrene Severity Index Scale (FGSI)

\begin{tabular}{|c|c|c|c|c|c|c|c|c|c|}
\hline \multirow[t]{2}{*}{ Parameter } & \multicolumn{9}{|c|}{ The norm } \\
\hline & $\begin{array}{c}+4 \\
\text { Points }\end{array}$ & $\begin{array}{c}+3 \\
\text { Points }\end{array}$ & $\begin{array}{c}+2 \\
\text { Points }\end{array}$ & $\begin{array}{c}+1 \\
\text { Points }\end{array}$ & $\begin{array}{c}0 \\
\text { points }\end{array}$ & $\begin{array}{c}+1 \\
\text { Points }\end{array}$ & $\begin{array}{c}+2 \\
\text { points }\end{array}$ & $\begin{array}{c}+3 \\
\text { Points }\end{array}$ & $\begin{array}{c}+4 \\
\text { Points }\end{array}$ \\
\hline Temperature (C) & $>41$ & $>39$ & & $36-38,4$ & $36-38,4$ & $34-35,9$ & $32-33,9$ & $<31,9$ & $<29,9$ \\
\hline Heart rate per Minute & $>180$ & $140-179$ & $110-139$ & & $70-109$ & & $55-69$ & $40-54$ & $<39$ \\
\hline Respiratory rate per minute & $>50$ & $35-49$ & & $25-34$ & $12-24$ & $10-11$ & $6-9$ & & $<5$ \\
\hline Sodium (mmol/l) & $>180$ & $160-179$ & $155-159$ & $150-154$ & $130-149$ & & $120-129$ & $111-119$ & $<110$ \\
\hline Potassium (mmol/l) & $>7$ & $6-6,9$ & & $5,5-5,9$ & $3,5-5,4$ & $3-3,4$ & $2,5-2,9$ & & $<2,5$ \\
\hline Creatinine $(\mu \mathrm{mol} / \mathrm{l})$ & $>3,5$ & $2-3,4$ & $1,5-1,9$ & & $0,6-1,4$ & & $<0,6$ & & \\
\hline Hematocrit (\%) & $>60$ & & $50-59,9$ & $46-49,9$ & $30-45,9$ & & $20-29,9$ & & $<20$ \\
\hline Leukocytes $\left(10^{*} 9 / \mathrm{l}\right)$ & $>40$ & & $20-39,9$ & $15-19,9$ & $3-14,9$ & & $1-2,9$ & & $<1$ \\
\hline Bicarbonate (mmol/l) & $>52$ & $41-51,9$ & & $32-40,9$ & $22-31,9$ & & $18-21,9$ & $15-17,9$ & $<15$ \\
\hline
\end{tabular}

On palpation crepitation and intensive pain are observed. Swelling spreads to the inguinal area and to the anal canal. Per rectum: infiltration at the height of the finger is palpable to the right of the anal canal, sphincter tone is increased, purulent discharge from the anterior crypt on a mirror examination.

Taking into account tachypnoe and arterial hypotension, according to the criteria of qSOFA scale - 2 points, the patient was hospitalized into the intensive care unit with the diagnosis:

Basic: Acute anterior ischiorectal abscess.

Complications: Necrotic fasciitis of the perineum. Fournier gangrene. Sepsis

Concomitant: Type II diabetes mellitus, severe course, decompensation.

Laboratory tests were carried out: Total blood count: $\mathrm{Hb}-100$ g / 1, Er - 3.42x1012 / 1, L - 18.2x109 / 1. Leukocyte formula: eosinophils - $2 \%$, rod neutrophils $13 \%$, segmented neutrophil - 62\%, lymphocytes - $20 \%$, monocytes - 3\%, ESR - $24 \mathrm{~mm} / \mathrm{h}$. Hematocrit - 48\%, Platelets - $150 \times 109$ / l. Biochemical blood tests: creatinine - $150 \mathrm{mmol} / \mathrm{l}$, bilirubin - $27.4 \mathrm{mmol} / \mathrm{l}$., $\mathrm{Na}-140$ mmol / 1., K -5.4 mmol / 1., Bicarbonate - $30 \mathrm{mmol} / \mathrm{l}$, Blood sugar - $21 \mathrm{mmol} / 1$.

After intensive preoperative preparation - infusion therapy with crystalloids in volume of $2000 \mathrm{ml}$., empirical antibacterial therapy is prescribed in accordance with the recommendations of "Sanford Guide" 2012: clindamycin i.v. 900 mg. every 8 hours; benzylpenicillin i.v. 24 million units. per day in 4 infusions; metronidazole $500 \mathrm{mg}$.; insulin correction of sugar. The patient is taken for surgery within 3 hours of hospitalization.

Anesthesia: Epidural

Surgery course: Processing of the operating field with antiseptics, opening of pararectal abscess. Zaremba test was conducted to verify the internal opening of paraproctitis, which was determined at 12 hours. Wide opening of ishiorectal space. $200 \mathrm{ml}$ of purulent content with blood threads was evacuated. Bacterial culture was taken. The inner paraproctitis hole is excised by Gabriel (histological study). Perineum, scrotum, right and left inguinal area, dorsal surface of the penis are opened with wide incisions. Fasciotomy, ultrasound necrectomy within healthy tissues (histological examination) are performed. Control for hemostasis. The cavity is sanitized with Pulse lavage sysyem with the use of oxidizing agents ( $\mathrm{H} 2 \mathrm{O} 2)$ and ozonized solution. Drainage of ishiorectal space, purulent pouches of the perineum, groin, and scrotum with rubber drainages, PCV paired drainages. A rinse system with oxidants is installed. Aseptic bandage. Results of microbiological investigation: E. coli, St. Epidermidis.

The dressings were performed twice a day, under narcotic analgesia (sol. Morphini), staged necrectomies for three days. 
On the 4th day, KCI Acti VAC system of active aspiration was installed for three days.

After purification of the wounds from necrotic changed tissues on 12th day secondary sutures were performed.

According to the integral scale SOFA, the patient has 2 points, which corresponds to the presence of a patient with sepsis. According to the Fournier Gangrene Severity Scale, $\mathrm{FG}=10$ points with a predicted lethality of $75 \%$. The patient is discharged on the 16th day in a satisfactory condition under the supervision of a general practitioner.

\section{DISCUSSION}

In the spread of inflammatory process on the cellular spaces of the pelvis, high localization of the inflammatory process, which has "rotten", anaerobic nature, in the clinical picture of the disease symptoms of intoxication come to the fore. [10] In diabetic patients, acute purulent diseases have a more difficult course, with the rapid formation of bulk tissue necrosis and the development of sepsis. [11] Due to the complexity of the cultivation and identification of anaerobic microflora, the primary diagnosis of anaerobic paraproctitis is based on clinical and intraoperative data. Microscopy of surgical specimens, examination of exudate are performed to clarify the diagnosis, ultrasonography, and computed tomography are performed when the process is spread in adjacent cellular spaces. [12]

Therefore, treatment of RA is a complex of therapeutic measures, which include careful surgical intervention and conservative correction of endogenous intoxication, sepsis. [13]

According to the latest data (Sepsis-3, 2016), the definition of organ dysfunction is performed using the SOFA scale (Sepsis Related (sequential) organ failure assessment) in combination with the Glasgow coma scale. Zero value on the SOFA scale indicates a lack of organ dysfunction. Today, SOFA has the most complete clinical confirmation of informational significance with the minimal use of constituent parameters. Thus, the diagnostic criteria for sepsis are as follows: - suspicion of infection or documented infection; - organ dysfunction (two points or more on the SOFA scale). Tab. I

The identification of patients with septic shock, according to «Sepsis-3», is proposed based on: a clinical picture of sepsis against adequate infusion therapy, an increase in blood lactate levels greater than $2 \mathrm{mmol} / \mathrm{l}$, and stable hypotension requiring the infusion of vasopressors to maintain MAP $\geq 65 \mathrm{~mm} \mathrm{Hg}$. [14]

For a systematic assessment of the severity of the patient's condition with FG and the prognosis of the disease, various systems for operative assessment of the patient's condition and his recovery chances are proposed, known as screening systems: Fournier's Gangrene Severity Index (FGSI) (Table II).

Assessment of the distribution of FG: FG restricted urogenital / anorectal region, +1 point, FG is limited to the pelvis, +2 points; FG beyond the border of the pelvis, +6 points. Estimation of age: Age $\geq 60$ years, +1 point.
By means of regression analysis, high prognostic value of the FG index was shown: a strong correlation between FGSI and the result of the disease was found (correlation coefficient $=0.934, p=0.005$ ). At the threshold values of FGSI $>9$ points, the likelihood of a fatal outcome is $75 \%$, with FGSI values $\leq 9$ points, the probability of a successful outcome is $78 \%(\mathrm{p}=0.008)$. The predictive value of FGSI is shown by many authors. [15]

\section{CONCLUSIONS}

Rectal abscess, which is complicated by the NF of the perineum, FG is characterized by severe course and high mortality.

The qSOFA, SOFA integral scales will allow you to suspect and further to verify sepsis and septic shock, allowing timely initiation of adequate therapy.

The FG severity assessment scale allows you to predict the course and treatment outcome for the necrotic lesion of the facial spaces of the perineum.

Early surgical treatment, adequate necrectomy, fasciotomy and antibacterial therapy stop the necrotic process.

The use of active aspiration reduces the timing of wound cleansing and further ensures the accelerated implementation of reconstructive surgical interventions.

\section{REFERENCES}

1. Sevost'janov S.I., Sharmazanashvili D.0. Klinicheskoe techenie ostrogo paraproktita u lic pozhilogo i starcheskogo vozrasta. Materialy I sezda koloproktologov SNG. Tashkent, 2009: 233.

2. Adamo K., Sandblom G., Brännström F., Strigård K. Prevalence and recurrence rate of perianal abscess--a population-based study, Sweden 1997-2009. Int J Colorectal Dis 2016; 356: 669-73. doi:10.1007/s00384015-2500-7 pmid:26768004

3. Alekseevnina V.V., Lebed'A.A., Olifirova 0.S., Bregadze A.A. Primenenie elektroaktivirovannyh rastvorov v hirurgicheskoj praktike. Bjulleten' Vostochno-Sibirskogo nauchnogo centra SO RAMN 2011; 4: 18.

4. Ommer A, Herold A, Berg E. et al. Cryptoglandular anal fistulas. Dtsch Arztebl Int. 2011 0ct; 108 (42):707-13. doi: 10.3238/arztebl.2011.0707. Epub 2011 0ct 21.

5. Privol'nev V.V., Pleshkov V.G., Kozlov R.S., Savkin V.A., Golub A.V. Diagnostika i lechenie nekroticheskih infekcij kozhi i mjagkih tkanej na primere gangreny Furn'e. Stacionarozameshhajushhie Tehnologii: Ambulator hirurgija. 2015 ; (3-4):50-57.

6. Goh T., Goh L.G., Ang C.H., Wong C.H. Early diagnosis of necrotizing fasciitis. Br J. Surg (2014) 101:119-25

7. Borsova F. Z., Mun M. N., Dudnik V. Ju., Open'ko V. G. Kombinirovannoe primenenie ozona i jeritrocitarnyh farmakocitov pri lechenii ostrogo paraproktita.Problemy koloproktologii: sbornik statej. M.: ID «Medpraktika-M». 2006;19:34-38.

8. Adrienne J. Headley M.D. Necrotizing soft tissue infections: a primary care review. American family physician. 2003;68(2):323-328.

9. Dem'janov A.V., Andreev A.A. Ostryj paraproktit. Obzor literatury.Vestnik eksperimental'noj i klinicheskoj hirurgii. 2013;6(4):526-534.

10. Nijazov A.Sh. Ispol'zovanie infrakrasnogo lazernogo izluchenija i proteoliticheskih fermentov v kompleksnom hirurgicheskom lechenii bol'nyh s anorektal'noj patologiej. Lazernaja medicina. 2007;11:(4)16-18. 
11. Kihtjak 0. P. Mehanizmi rozvitku insulinorezistentnosti ta ïi misheni. Ukraïns'kij medichnij chasopis, 5(97)2013;9/10:99-102.

12. Sevost'janov S.I., Konovich E.A., Sharmazanashvili D.0. Koloproktologija, 2010;3:33

13. Dellinger RP, Levy MM, Rhodes A. et al. Surviving Sepsis Campaign: international guidelines for management of severe sepsis and septic shock, 2012. Intensive Care Med. 2013;39 (2):165-228

14. Laor E., Palmer L.S., Tolia B.M., Reid R.E., Winter H.I. Outcome prediction in patients with Fournier's gangrene. J. Urol. 1995;154(1):89-92.

15. Timerbulatov M.V.Anajerobnyj paraproktit. Koloproktologija. 2012;2(40):4-9.

\section{ORCID and contributionship:}

Oleh E. Kanikovskyi - 0000-0002-9302-8760 E

Andrii V. Osadchyi - 0000-0002-8910-0328 ${ }^{A, B, C, D}$

Sergey I. Androsov - 0000-0003-0827-8288

Anatolii V. Tomashevskyi - 0000-0001-8519-0488

Oleh A. Yarmak - 0000-0002-4103-7614

Valentyn S. Bakhnivskyi - 0000-0003-3280-9456 ${ }^{F}$

\section{Conflicts of interest:}

Authors declare no conflict of interest.

\section{CORRESPONDING AUTHOR Valentyn S. Bakhnivskyi \\ Stefan Żeromski Hospital in Cracow, \\ Cracow, Poland \\ tel: +48576588771 \\ mail: valentyn.bakhnivskyi@poczta.pl}

Received: 13.08.2019

Accepted: 19.12 .2019

A - Work concept and design, B - Data collection and analysis, C - Responsibility for statistical analysis,

D-Writing the article, $\mathbf{E}$-Critical review, $\mathbf{F}$ - Final approval of the article 